\title{
Konseptual Aplikasi Peta Trapesium Plot Pasture (Peta TPP) pada Pengukuran Produksi Hijauan Pakan Ternak Berdasarkan Citra Media Foto (CMF) dan Citra Media Tulis (CMT) Untuk Informasi Grafis Secara Vertikal Berskala
}

\author{
Delvia Nora $^{1 *}$ \\ ${ }^{1}$ Animal Husbandry Study Program, Faculty of Agriculture, Muara Bungo University \\ *Corresponding author: delvianora@yahoo.com
}

\begin{abstract}
Abstrak
Luasan lahan yang mengalami perubahan fungsi lahan memiliki beberapa kecirian khusus yang berbeda-beda dalam potensi sumber daya alam. Kekuatan potensi sumber daya alam suatu daerah mempengaruhi kebijakan yang akan sehingga diperoleh suatu kebijakan yang berwawasan lingkungan dan menjamin keberlangsungan suatu sumber daya. Harapan yang diharapkan adalah yang memiliki kontribusi umum dan menguntungkan masyarakat baik sebagai usaha utama maupun sebagai usaha sampingan yang dapat diubah menjadi usaha utama. Untuk itu diperlukan suatu pendekatan lingkungan secara langsung baik dengan pengamatan dan mengumpulkan instrumentinstrumen yang jelas untuk mendukung suatu metodologi yang tepat dan memiliki hasil yang mendekati bahkan sesuai pengukurannya sehingga diperoleh kondisi sesuangguhnya dari suatu lingkungan. Peta TPP digunakan untuk mengetahui beberapa indikator berdasarkan atas kajian lapangan pada lokasi yang berbeda topografinya dan memiliki jangkauan pengukuran yang luas. Selama ini pengukuran hanya menjangkau beberapa lokasi dan model tertentu, sehingga diharapkan dapat digunakan metoda yang bervariasi dalam mengukur produktifitas lahan dalam luasan tertentu untuk mendapatkan pendekatan-pendekatan yang mendasar untuk memperkuat asumsi dan prediksi produksi suatu lahan dalam menghasilkan hijauan terutama pada lahan yang bersifat alami, disamping dapat juga digunakan pada pemetaan lahan budidaya. Metoda yang digunakan dalam penelitian ini adalah Manajerial pengukuran produktifitas lahan secara vertikal dengan menghitung : A.Pengelolaan Data Pengukuran Produksi Lahan Budidaya, B. Pengelolaan Data Produksi Lahan Sub Optimal, C) Pengelolaan Data Produksi Lahan Sub Optimal meliputi :1) Teknis Pengukuran Tahap-1Teknik pengukuran produksi diawali CMF berdasarkan hasil dokumentasi yang dilanjutkan dengan CMT. Instrument-instrumen pengukuran menggunakan media tertulis mengikuti derajatderajat pada CMF untuk mengetahui RK Aman, penampang utama grafis lahan, tata kelola lahan dengan strategi resiko kemiringan lahan, 2) Teknis Pengukuran Tahap-2. Berdasarkan hasil penelitian Peta TPP dapat mengukur produksi suatu lahan secara vertikal berdasarkan CMT, CMF tersendiri.
\end{abstract}

Kata kunci: Konseptual, Aplikasi, Peta TPP, Produksi, CMT

\begin{abstract}
The area of land that has undergone a change in land use has several special characteristics that vary in natural resource potential. The potential strength of a region's natural resources influences the policies that will result in a policy that is environmentally sound and guarantees the sustainability of a resource. The hope that is expected is that which has a general contribution and benefits the community both as a main business and as a side business that can be turned into a main business. For this reason, a direct environmental approach is needed both by observing and collecting clear instruments to support an appropriate methodology and having results that are close to and even according to the measurements so that the proper conditions of an environment are obtained. The TPP map is used to determine several indicators based on field studies at locations
\end{abstract}


Prosiding Seminar Nasional Pembangunan dan Pendidikan Vokasi Pertanian Politeknik Pembangunan Pertanian Manokwari, 14 November 2020

e ISSN : 2774-1982

that differ in topography and have a wide measurement range. So far, the measurement only covers certain locations and models, so it is hoped that various methods can be used to measure land productivity in a certain area to obtain basic approaches to strengthen assumptions and predictions of land production in producing forage, especially on natural lands. Besides can also be used in mapping cultivated land. The method used in this research is Managerial measurement of land productivity vertically by calculating: A. Management of Measurement Data for Cultivated Land Production, B. Management of Sub-Optimal Land Production Data, C) Management of SubOptimal Land Production Data, including: 1) Technical Measurement Stage- 1 Production measurement technique begins with CMF based on the results of documentation followed by CMT. measurement instruments use written media following the degrees on the CMF to find out the Safe $R K$, the main land graphic section, land management with a land slope risk strategy, 2) Measurement Technique Phase-2. Based on the research results, the TPP map can measure the production of a land vertically based on CMT, CMF alone.

Keywords: Conceptual, Application, TPP Map, Production, CMT

\section{PENDAHULUAN}

Potensi, kelemahan, peluang dan ancaman suatu daerah yang berbeda akan memberikan informasi lingkungan yang luas dan beragam. Potensi pengembangan sapi tertinggi berturut-turut (dari tinggi ke rendah populasinya) berada di Kabupaten Sungai Penuh, Kabupaten Bungo, Kota Jambi, Kabupaten Batang Hari dan Kabupaten Tebo. Sedangkan Kabupaten Kerinci, Kabupaten Merangin, Kabupaten Sarolangun, Kabupaten Muaro Jambi, Kabupaten Tanjung Jabung Timur dan Kabupaten Tanjung Jabung Barat merupakan kabupaten dengan potensi yang mengalami dinamika, cenderung mengalami perubahan karena dipengaruhi oleh jumlah penduduk yang selalu linier dengan peningkatan maupun penurunannnya. Optimalisasi wilayah ada di kabupaten yang memiliki potensi integrasi, karena setiap komoditi yang dikembangkan bila disinergitaskan denah usaha masyarakat dapat memberikan pendapatan yang lebih terjamin, dan potensi yang ada akan lebih bertahan dalam setiap situasi perubahan lingkungan alam. Strategi adalah pilihan tentang apa yang ingin dicapai oleh suatu organisasi dimasa depan dan bagaimana cara mencapai keadaan yang diinginkan tersebut (Nora, 2020a).

Penerapan sinergitas tidak terlepas dari beberapa peranan pelaksana usaha pengembangan suatu komoditi unggulan daerah, keunggulan tersebut merupakan bentuk hasil usaha pelaksanaan kebijakan. Namun, tidak semua peluang usaha tersebut dapat dilaksanakan dengan sepenuh hati, hal ini dijabarkan secara pendekatan lingkungan sebagai sumber permasalahan ketidak tepatan program yang dilaksanakan salah satunya akibat permasalahan permanen yang timbul sehingga menghambat bertahannya suatu komoditi daerah. Salah satu jawaban solusi yang akan diterapkan dalam Peta TPP saat ini adalah 
Prosiding Seminar Nasional Pembangunan dan Pendidikan Vokasi Pertanian

Politeknik Pembangunan Pertanian Manokwari, 14 November 2020

e ISSN : 2774-1982

mengembangkan suatu keunggulan tanpa memberikan perubahan merugikan bagi lingkungan, sehingga selain usaha lebih terjamin juga sumber daya alam sebagai kekuatan potensi wilayah dapat bertahan lama dan diarahkan untuk pencapaian sasaran yng tepat dan menguntungkan sepanjang waktu tanpa harus merugikan kekayaaan sumber daya alam tersebut karena bersifat melestarikan lingkungan berjangka panjang. Disinilah letak pengambilan kebijakan sebagai dasar untuk mensinergiskan usaha dengan lingkungan dan pemanfaatannya dalam satu kebijakan prioritas berlandaskan lingkungan, dan kebijakan alternatif sebagai pendukung untuk menjawab semua masalah dalam berbagai variabelvariabel pengukuran kualitas lingkungan sebelum menetapkan suatu kebijakan prioritas.

Pengembangan usaha inti dan kemungkinan pengembangan usaha yang lain memerlukan suatu terobosan kebijakan yang berwawasan alami dan ekonomi kemasyarakatan termasuk pengembangan lahan yang menjadi program pengembangan suatu komoditi dan sumber daya lainnya yang berbasis kekayaan lokal. Beberapa instrument penting perlu diperhatikan sebelum memikirkan kebijakan yang akan diprogramkan dalam suatu perencanaan wilayah seperti pengembangan program lumbung pakan. Menurut Mandarisa (2013) variabel penelitian dan pengukuran meliputi: 1) demografi dan topografi wilayah, 2) ketersediaan pakan berdasarkan luas lahan pertanian, tanaman pangan dan limbah hasil pertanian, dan 3) jumlah ternak sapi, kerbau, kambing dan domba menurut daerah. Ditambahkan pula bahwa untuk pengukuran potensi menggunakan analisis data yaitu 1) analisis deskriptif, 2) analisa potensi bahan pakan, Indeks Daya Dukung (IDD) yaitu kemampuan wilayah yang meliputi wilayah sangat kritis (wilayah dengan IDD $\leq 1$ ); wilayah kritis(IDD $<1-1$,5; wilayah rawan(IDD=2); wilayah aman (IDD>2); dan Kapasitas Penambahan Ternak Ruminansia (KPTR). Perhitungan IDD adalah perbandingan antara total potensi pakan yang tersedia (BKC) dan total kebutuhan pakan (BKC), dimana BKC adalah jumlah pakan asal limbah pertanian (padi sawah, padi lading, jagung kedelai, kacang hijau, kacang tanah, ubi jalar dan ubi kaya) ditambah jumlah produksi hijauan alami menurut penggunaan lahan (sawah, lahan kering, perkebunan (karet, sawit, kelapa dalam, cengkah, vanili), perkarangan, tegarlan/kebun, lading/padang rumput, hutan rakyat, pagar hidup dan lain-lain, sehingga kemampuan daerah merupakan IDD dikali total populasi (ST). Sumber-sumberpenghasil rumput seperti padang rumput, sawah, galengan sawah, perkebunan, hutan, tepian jalan dan tegalan (Mandarisa, 2013).

Produksi Hijauan Makanan Ternak (HMT) beberapa penelitian dapat diukur dengan berbagai cara dan teknis pendekatan dilapangan dengan tujuan untuk mendapatkan kualitas dan kuantitas yang tinggi, namun teknik pengukuran produksi lapangan berskala 
Prosiding Seminar Nasional Pembangunan dan Pendidikan Vokasi Pertanian

Politeknik Pembangunan Pertanian Manokwari, 14 November 2020

e ISSN : 2774-1982

luas masih sedikit dilakukan terutama dengan tujuan untuk meningkatkan produktifitas HMT. Tingginya hasil evaluasi produksi akan mencerminkan kemampuan potensi lahan baik lahan tersebut lahan produktif (optimal) maupun lahan non produktif alami (sub optimal). Sumber-sumber pakan ternak selain berupa hijauan alami juga dapat berupa daundaunan dan hijauan limbah yang berasal dari bagian tubuh tumbuhan yang segar, sedangkan kualitas HMT tergantung pada lama atau cepatnya diberikan kepada ternak. Berbagai penanganan limbah digunakan untuk meminimalisir limbah yang terbuang percuma sebagai HMT dan meningkatkan nilai mutunya melalui teknik-teknik biologis dan variatif biologis.

Produksi HMT dari suatu lahan memerlukan penanganan yang tepat, penanganan ini diperlukan untuk mengetahui seberapa besar kontribusinya terhadap ketersediaan dan kemampuan lahan menghasilkan dalam jangka waktu tertentu. Mengetahui lamanya produksi HMT sebagai stok diperlukan untuk melihat interval pemanfaatannya bagi ketersediaan stok pakan. Menurut Mandarisa (2013) bahwa kemampuan lahan dalam menghasilkan rumput sebagai pakan (BKC) dikategorikan masing-masing kabupaten/kota menurut IDD adalah : 1 ) wilayah kritis $(1<\operatorname{IDD}<1,5), 2)$ wilayah rawan $(1,5<\operatorname{IDD}<2)$, dan 3) wilayah aman (IDD $>2$ ).

Metode diatas merupakan suatu metode pengukuran produksi berdasarkan produksi limbah yang dihasilkan dari suatu usaha masyarkat baik dibidang pertanian, perkebunan dan sebagainya yang menghasilkan limbah, sedangkan Peta TPP merupakan suatu metode yang baru untuk mengetahui : 1) produksi suatu lahan dengan skala luas dengan berbagai Kondisi topografi berbeda baik secara vertikal maupun secara horizontal dengan menggunakan rumus tertentu untuk mendukung perhitungan dari plot yang terbentuk dalam bentangan luasan tertentu suatu lokasi, 2) yang diduga dapat memberikan kontribusi HMT sebagai sumber pakan hijauan tanpa melakukan perubahan pada lahan, 3) tapi mempertahankan kondisi alami lahan tersebut sesuai kondisi aslinya dan pemanfaatan lahan hanya terbatas pada pengambilan HMT alami yang dimungkinkan untuk dimanfaatkan rumput dan legume yang ada didalamnya, 4) untuk memperjelas gambaran produktifitas yang bisa diperoleh melalui teknik pendekatan lingkungan secara langsung dan tidak langsung baik secara manual dan komputerisasi sehingga diperoleh hasil pengukuran produksi pendekatan kuantitasnya dengan memperhatikan instrumentinstrumen tertentu untuk metoda yang sesuai dengan kondisi alamnya, 5) dan dapat digunakan sebagai teknik perbandingan untuk mengetahui produksi suatu lahan terhadap HMT yang dihasilkan lahan budidaya (optimal) dan lahan non budidaya (sub optimal). 
Prosiding Seminar Nasional Pembangunan dan Pendidikan Vokasi Pertanian Politeknik Pembangunan Pertanian Manokwari, 14 November 2020

e ISSN : 2774-1982

Inti dari penelitian ini adalah memberlakukan pengujian dengan rumus berdasarkan data-data diatas sehingga disinkronisasikan menjadi suatu ukuran yang lebih praktis dan mudah diterapkan dalam suatu pengukuran yang memiliki banyak parameter pengukuran dapat memberikan informasi langsung tentang posisi lahan yang aman terhadap resiko penurunan lahan, kerusakan lahan akibat faktor alam dan kemungkinannya sehingga bersifat jangka panjang dalam keterjaminan penggunaan lahan untuk budidaya maupun usaha alami seperti pengembangan komoditi lokal atau unggulan yang dikembangkan untuk meningkatkan produksi suatu komoditi (Nora, 2020c).
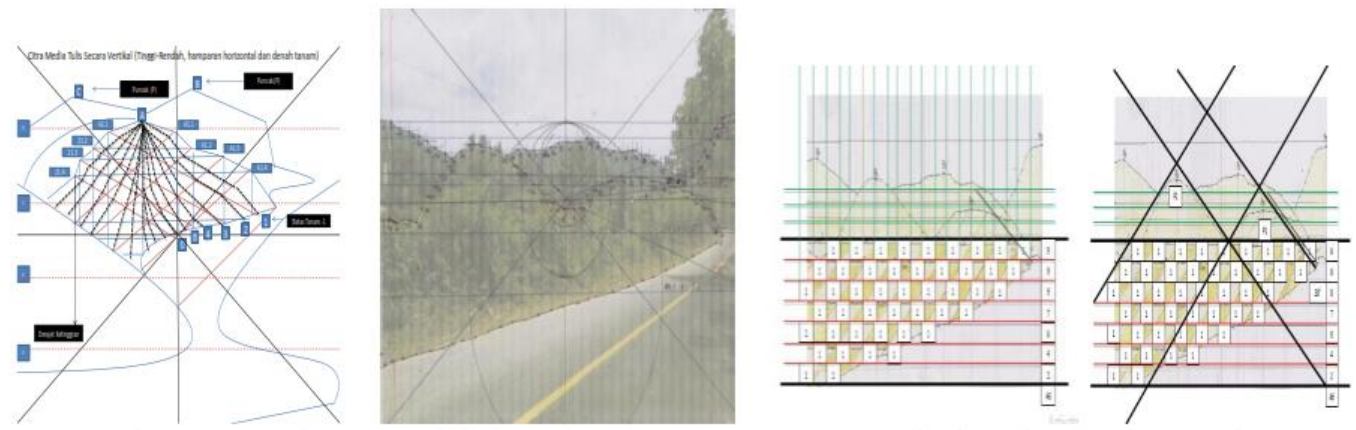

Gambar 1. Pengukuran Produksi Berdasarkan CMT Secara Vertikal Pada Lokasi Sampel M-8

Produktifitas lahan M-8 memiliki kekuatan potensi produksi dari perhitungan dengan CMT adalah sebesar 2.530 dengan berat $(\mathrm{kg})$ /populasi rata-rata.Lokasi Kabupaten Merangin diatas walaupun tidak termasuk dalam lokasi terpilih dalam Basic Mapping namun memiliki potensi untuk pengembangan HMT dengan topografi yang berbukit.

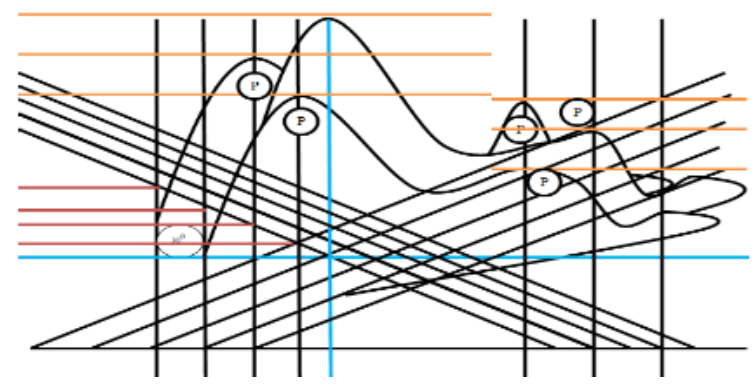

Gambar 2. Pemahaman Topografi Media Ukur Pada Peta TPP

Setelah mengetahui bagaimana konsep dasar survei awal lapangan terhadap hasil kajian lahan tentang point A, selanjutnya diperlukan evaluasi kesesuaian lahan dengan teknis penanaman yang akan direncanakan dengan memperhatikan hal berikut ini : 1) persiapan foto lahan secara vertical (tinggi-rendah) lokasi dapat dilihat dari dokumentasi lahan yang diambil dengan tujuan utuk dimasukkan pada analisis grafis dengan metode 
Prosiding Seminar Nasional Pembangunan dan Pendidikan Vokasi Pertanian

Politeknik Pembangunan Pertanian Manokwari, 14 November 2020

e ISSN : 2774-1982

pengukuran matematis yang meliputi : a) penandaan titik-titik pada batas gambar pada dokumentasi sampel lokasi yang dipilih berdasarkan kategori tertentu dalam penelitian, adapun penandaan titik-titik bertujuan untuk mendapatkan citra media tulis pada lembaran yang akan diukur dengan memberikan tanda batas dataran tinggi, sedang dan rendah yang mudah dilihat pembedanya dan memberikan garis-garis pembantu seperti garis vertikal dan horizontal beserta sudut pandang dalam derajat ketinggian secara vertikal.

Kondisi itu menyebabkan teknik pengembangan HMT kearah pemanfaatan pasture alami di Kabupaten Merangin memiliki pilihan pemanfaatan lahan berupa 1) pemanfaatan lahan alami/sub optimal yang cukup luas, 2) mengingat kemiringan rata-rata menunjukkan bahwa pengembangan lahan untuk budidaya pangan memiliki resiko penurunan tanah bila terjadi intensitas hujan yang tinggi, 3) dapat dimanfaatkan sebagai sumber hijauan yang melimbah secara alami tanpa harus merubah fungsi lahan sebagai lahan budidaya hijauan dalam waktu tertentu, 4) pemanfaatan lahan yang luas sebagai sumber hijauan dapat dijadikan rujukan sumber hijauan secara cut and carry. Pengukuran lahan dengan CMF dan CMT secara vertical di Kabupaten Merangin menunjukkan bahwa tingkat produksi dari lahan pengukuran diatas memiliki kontribusi yang tinggi. Adapun Perhitungan dapat dilihat pada analisis dibawah ini.

Berdasarkan gambar diatas, didapat hasil jumlah petakan dari dua puncak yang berbeda dengan jumlah (n) terhadap luasan setara 1 hektar dengan populasi yang jumlahnya sama dalam setiap petakan (55 populasi) sedangkan untuk lahan alami atau sub optimal diperoleh dengan mengambil sampel sebanyak petakan yang terbentuk. Adapun jumlah petakan digambarkan dibawah ini.

Perhitungan petakan diatas, menunjukkan bahwa nilai produktifitas dapat diketahui bila pengambilan sampel pada cluster diketahui. Hasil perhitungan berat dari penggunaan cluter pada Peta TPP menunjukkan hasil produksi sesungguhnya pada lahan yang diukur dengan penimbangan. Dengan demikian berapapun luasan lahan tetap akan diketahui hasil CMT dari CMF lokasi dengan cepat. Untuk membuktikannya tinggal melakukan percobaan di lapangan dengan menggunakan petunjuk pada cluster-cluster Peta TPP. Pengukuran produksi dapat dilakukan sesuai dengan kondisi lahan apakah lahan tersebut merupakan lahan budidaya (optimal) maupun lahan non budidaya (sub optimal).

\section{A. Pengelolaan Data Pengukuran Produksi Lahan Budidaya (Nora, 2020)}

Pengukuran Produksi Hijauan Menurut Peta TPP dilakukan dengan tahapan dibawah ini:

1. Pengambilan cuplikan dilakukan secara acak dan sistematik (Reksohadiprodjo, 1994) yang dimulai dari titik yang telah ditentukan kemudian cuplikan-cuplikan 
Prosiding Seminar Nasional Pembangunan dan Pendidikan Vokasi Pertanian Politeknik Pembangunan Pertanian Manokwari, 14 November 2020

e ISSN : 2774-1982

diambil dan jarak-jarak tertentu sepanjang garis yang memotong padang rumput dengan langkah-langkah sebagai berikut (Susetyo, 1998) dan teknis Peta TPP dilakukan dengan metode hasil komputerisasi yang akan memberikan informasi tentang jumlah petakan yang dihasilkan. Jumlah petakan dijadikan dasar penentuan petakan yang akan dibuat dengan keterjaminan kemiringan aman (RK Aman) berdasarkan penguatan hasil analisa.

2. Adapun sistematika langkah-langkah pada Peta TPP pada lahan adalah sebagai berikut: Petakan cuplikan pertama diletakkan secara acak.

3. Petak cuplikan kedua diambil pada jarak sepuluh langkah kekanan dan kekiri dari petak cuplikan pertama yang memiliki luas yang sama, ketiga petak ini berturutturut membentuk satu kumpulan (Cluster).

4. Cluster selanjutnya dilakukan pengambilan dengan jarak garis lurus dari cluster sebelumnya dengan berjarak 16 m mewakili 1/4 hektar pada Peta TPP dan lebih detail serta diperkecil pengambilan clusternya seluas 1 hektar, sedangkan pendapat Hanafi (2017) bahwa cluster selanjutnya yang diambil pada jarak lurus $125 \mathrm{~m}$ dari cluster sebelumnya, tiap satu cluster diambil mewakili area seluas 1,3 ha.

5. Hijauan yang terdapat di areal frame dipotong lebih kurang 5-10 $\mathrm{cm}$ diatas permukaan tanah dan ditimbang beratnya.
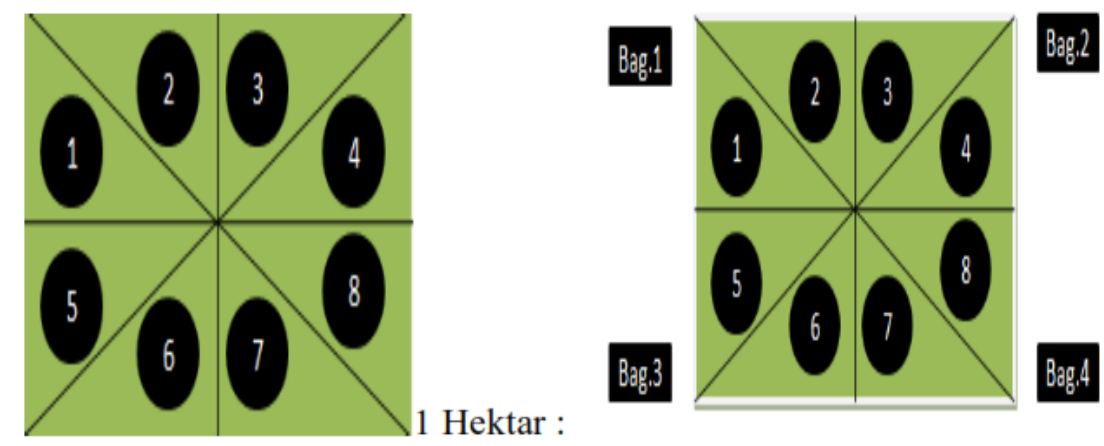

Gambar 3. Penetapan Cluster Pada Petakan (1 Hektar $=4$ petakan $)$

6. Hijauan tersebut dimasukkan kedalam amplop dan ditimbang berat segarnya (gram/m2). Kemudian dihitung rata-ratanya dan dikonversikan ke produksi per Ha.

7. Catatan berat segar tersebut dapat diketahui hijauan segar per $\mathrm{kg} / \mathrm{ha}$.

8. Perhitungan bahan kering dengan cara pengovenan menggunakan suhu $105^{\circ} \mathrm{C}$ selama 6 jam. 
Prosiding Seminar Nasional Pembangunan dan Pendidikan Vokasi Pertanian

Politeknik Pembangunan Pertanian Manokwari, 14 November 2020

e ISSN : 2774-1982

\section{B. Pengelolaan Data Produksi Lahan Sub Optimal (Nora, 2020c)}

Penilaian besaran sumber daya lokal semestinya dilakukan terlebih dahulu sebelum dilakukan kajian lapangan. Data-data primer lapangan yang diperoleh pada penelitian pendahuluan dapat memberikan informasi awal untuk informasi lanjutan tentang apa yang akan diterapkan pada lahan yang akan dikelola dan kemungkina apakah bisa suatu lahan dalam suatu wilayah dapat dikembangkan untuk tujuan kebijakan lahan yang memiliki fungsi lebih besar terhadap kontribusi pendapatan masyarakat dan produktifitas pengukuran instrument-instrumen lapangan untuk tujuan khusus pengembangan suatu kebijakan alternatif menjadi kebijakan prioritas (Nora, 2020a).

Sedangkan untuk Pengaturan pengelolaan data produksi seperti tahapan dibawah ini :

1. Hasil pengelolaan pengukuran lahan berdasarkan kuadran dengan metoda TPP diterapkan sesuai dengan tahapan yang ditentukan untuk menghitung produksi hijauan

2. Pengambilan cuplikan sampel yang akan diukur berdasarkan tahapan sebagai berikut:

1) Ketentuan bahwa setiap luasan 1 hektar lahan terdiri dari 4 bagian besar lahan dengan kode lahan A,B, C dan D

2) Setiap lahan utama tersebut dilakukan pengukuran dengan tahapan pengukuran produksi dengan menggunakan kuadran

3) Pengukuran khusus lahan budidaya dapat dilakukan dengan teknis yang meliputi: 1) jarak tanam merupakan kunci penentuan populasi hijauan yang ditanam dalam petakan utama dengan perhitungan sebagai berikut :

a. Sebagai contoh rumput yang ditanam dengan jarak 10 x $15 \mathrm{~m}$ memiliki populasi sekitar 666-667 tanaman rumput untuk satu petakan utama (4 bagian petakan utama diatas)

b. Pembibitan rumput dilakukan sebelum tanam dilahan dapat dihitung berdasarkan pada hitungan berdasarkan pengelolaan lahan dengan mekanisme tahunan (12 bulan) usaha pembibitan dengan kapasitas bibit yang harus disiapkan dalam sirkulasi sebanyak 55-56 bibit setiap bulan

c. Jumlah bibit antara 55-56 tersebut dengan luasan lahan yaitu 8.250-8.400 meter diperoleh 12 petakan pengaturan tanam dalam 1 hektar lahan

d. Pola pengaturan tanam bibit diperoleh dari berdasarkan masa panen yang ditentukan, biasanya antara 40-60 hari untuk pemanenan pertama sehingga diperoleh masa terjauh adalah 60 hari untuk penentuan masa tanam. 
Prosiding Seminar Nasional Pembangunan dan Pendidikan Vokasi Pertanian Politeknik Pembangunan Pertanian Manokwari, 14 November 2020

e ISSN : 2774-1982

e. Masa tanam diperoleh dari kombinasi pengaturan plot dibawh ini.

f. Jumlah Trapesium akan ditampilkan berdasarkan pada pengaturan plot yang muncul. (Nora, 2020c)

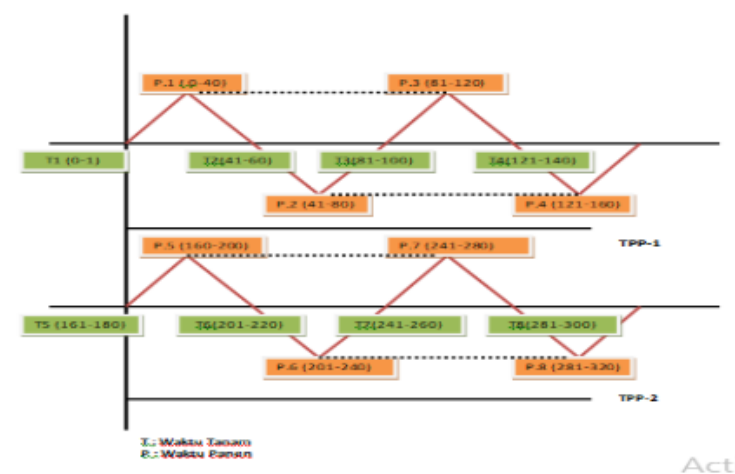

Gambar 4. Pola Tanam dan Panen dan Pengambilan Sampel Untuk Lahan Budidaya

Berdasarkan hasil analisis diatas, bahwa pola tanam pada lahan budidaya juga dapat dihitung dengan menggunakan Peta TPP sejak awal pengambilan sampel produksi HMT sebagai gambaran potensi suatu lokasi. Untuk melihat besaran produktifitas HMT dapat dilihat pada gambar dibawah ini.

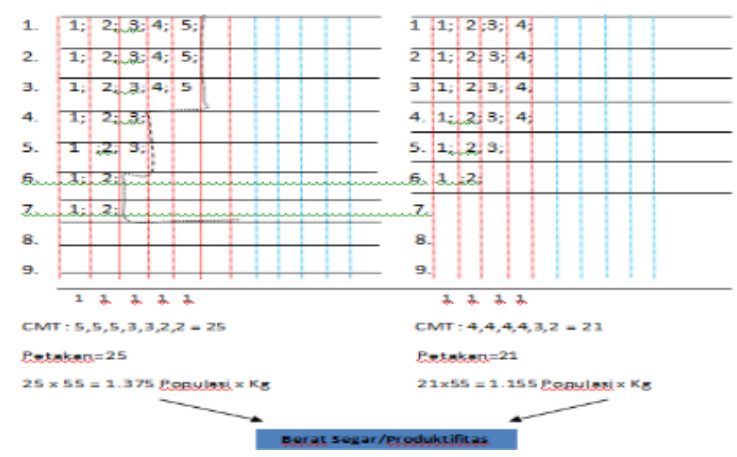

Gambar 5. Produktifitas Lahan M-8

Berdasarkan gambar diatas bahwa model tanam dan panen maupun pengambilan cluster yang teratur akan memberikan informasi produksi yang jelas dan dapat dianalisa untuk melihat peningkatan dan penurunan kualitas kondisi tanaman terhadap kondisi lingkungan, sehingga bila diperlukan suatu usaha perbaikan atau modivikasi teknis tertentu dapat dilakukan dengan secepatnya. Teknik pengaturan penanaman digunakan yang terpendek yaitu 40 hari bagi tanaman hijauan budidaya dan kluster yang sesuai petunjuk Peta TPP untuk mendapatkan kedekatan nilai produksi yang diinginkan karena cluster yang diambil dengan teknis yang berurut dan mencakup luasan yang terukur dengan jelas (Nora, 2020c). 


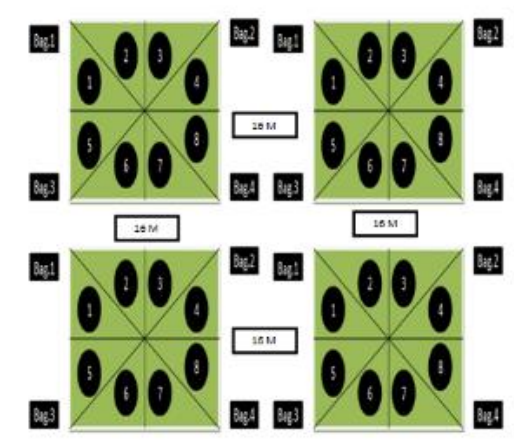

Gambar 6. Teknik Pengambilan Cluster Setara 1 Hektar

\section{Pengelolaan Data Produksi Lahan Sub Optimal}

Sedangkan untuk Pengaturan pengelolaan data produksi seperti tahapan dibawah ini :

1. Hasil pengelolaan pengukuran lahan berdasarkan kuadran dengan metoda TPP diterapkan sesuai dengan tahapan yang ditentukan untuk menghitung produksi hijauan

2. Pengambilan cuplikan sampel yang akan diukur berdasarkan tahapan sebagai berikut:

a. Ketentuan bahwa setiap luasan 1 hektar lahan terdiri dari 4 bagian besar lahan dengan kode lahan A,B, C dan D

b. Setiap lahan utama tersebut dilakukan pengukuran dengan tahapan pengukuran produksi dengan menggunakan kuadran

c. Pengukuran khusus lahan budidaya dapat dilakukan dengan teknis yang meliputi: jarak tanam merupakan kunci penentuan populasi hijauan yang ditanam dalam petakan utama dengan perhitungan sebagai berikut :

1) Sebagai contoh rumput yang ditanam dengan jarak $10 \times 15 \mathrm{~m}$ memiliki populasi sekitar 666-667 tanaman rumput untuk satu petakan utama (4 bagian petakan utama diatas)

2) Pembibitan rumput dilakukan sebelum tanam dilahan dapat dihitung berdasarkan pada hitungan berdasarkan pengelolaan lahan dengan mekanisme tahunan (12 bulan) usaha pembibitan dengan kapasitas bibit yang harus disiapkan dalam sirkulasi sebanyak 55-56 bibit setiap bulan

3) Jumlah bibit antara 55-56 tersebut dengan luasan lahan yaitu 8.250-8.400 meter diperoleh 12 petakan pengaturan tanam dalam 1 hektar lahan 
Prosiding Seminar Nasional Pembangunan dan Pendidikan Vokasi Pertanian Politeknik Pembangunan Pertanian Manokwari, 14 November 2020

e ISSN : 2774-1982

4) Pola pengaturan tanam bibit diperoleh dari berdasarkan masa panen yang ditentukan, biasanya antara 40-60 hari untuk pemanenan pertama sehingga diperoleh masa terjauh adalah 60 hari untuk penentuan masa tanam.

5) Masa tanam diperoleh dari kombinasi pengaturan plot dibawh ini.

6) Jumlah Trapesium akan ditampilkan berdasarkan pada pengaturan plot yang muncul.

\section{Teknis Pengukuran Tahap-1}

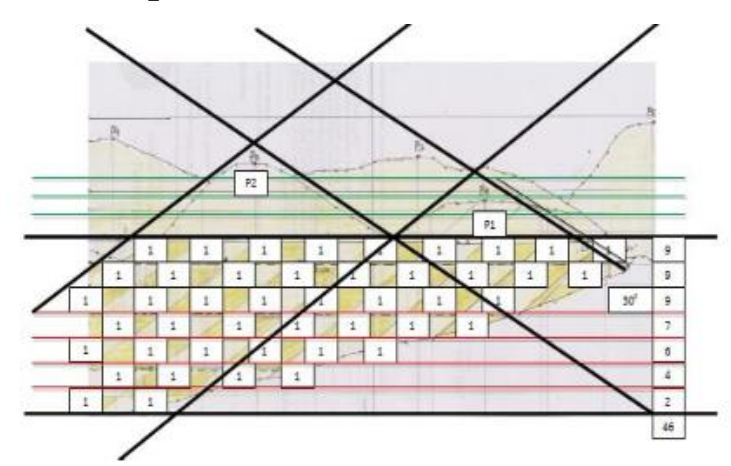

Gambar 7. Teknik Pengukuran Tahap-1

Teknik pengukuran produksi diawali CMF yang didapatkan dari lapangan berdasarkan hasil dokumentasi yang dilanjutkan dengan CMT. CMT merupakan tahapan pertama yang digunakan untuk memulai pengukuran produksi berdasarkan Peta TPP dengan melakukan beberapa instrument-instrumen pengukuran sebagai berikut:

1. Menggunakan media tertulis dengan mengikuti derajat-derajat pada CMF untuk mengetahui ukuran-ukuran batasan Resiko Kemiringan(RK) Aman dan line (L) :

a. Penampang Utama Grafis Lahan

Nora, 2020b menyatakan bahwa pengukuran instrument pada kondisi ini memberikan penjelasan bahwa : 1) bila daya dorong dari lingkungan (hujan) berasal dari A (diatas atau dibawah A ) yang berasal dari A (puncak) maka arah penurunan antara X2 dan C (sebagai garis batas erosi) dengan dua garis utama batas erosi yaitu A-X merupakan garis batas erosi tanah terhadap faktor lingkungan atau $\mathrm{H}$ (hujan) dimana A sebagai puncak aktif yang berfungsi sebagai penahan atau daya topan lahan terhadap faktor $\mathrm{H}$ dan $\mathrm{A}-\mathrm{X}$ merupakan garis batas erosi tanah terhadap $\mathrm{H}$ (hujan) dimana A sebagai puncak aktif pendorong arah penurunan tanah bukan sebagai penopang tetapi sebagai pelepas beban sebelumnya sehingga kekuatan arah penurunan semakin besar bila semakin kebawah terhadap C. Arah penurunan tanah cepat atau lambat dipengaruh juga oleh banyak atau tidaknya media penopang yang menghambat arus penurunan tanah, akibatnya semakin 
Prosiding Seminar Nasional Pembangunan dan Pendidikan Vokasi Pertanian Politeknik Pembangunan Pertanian Manokwari, 14 November 2020

e ISSN : 2774-1982

banyak penopang pada garis batas erosi tanah maka mengakibatkan semakin memperkecil daya longsor tanah (misalnya pada teknik sengkedan/ sawah yang berjenjang yang sering diterapkan di Indonesia), bila sebaliknya maka arah penurunan tanah akan semakin cepat akibat daya dorong faktor lingkungan dari $\mathrm{H}$ (hujan), 2) bila daya dorong dari lingkungan (hujan) berasal dari titik A dan media penahan $\mathrm{C}$ tidak ada daya tahan lagi $(\mathrm{c}=0)$ dari $\mathrm{H}$ dan $\mathrm{td}-\mathrm{n}$ hanya sebagai penahan terakhir maka $\mathrm{C}$ dikatakan sebagai penahan super aktif dari daya dorong semua instrument penyebab arah penurunan lahan dari puncak lahan sehingga $\mathrm{C}$ adalah lokasi yang melepas daya dorong dari $\mathrm{H}$ secara bebas sampai nilai $\mathrm{C}=0$ dan wilayah C merupakan wilayah berbahaya (besarnya daya erosi terbesar dan daerah imbas penurunan lahan akibat $\mathrm{H}$ ).

b. Tata Kelola Lahan Dengan Strategi Resiko Kemiringan Lahan

Lahan yang memiliki kemiringan dan datar merupakan lahan yang memiliki teknik berbeda dalam pengukuran dan hasil analisis serta pengukuran produksi HMT. Untuk mengetahuinya terlebih dahulu harus mengamati karakteristik lahan dan faktor-faktor yang mempengaruhi pembentuk grafis lahan secara manual (CMT) dan secara teknosatelit (CMF).

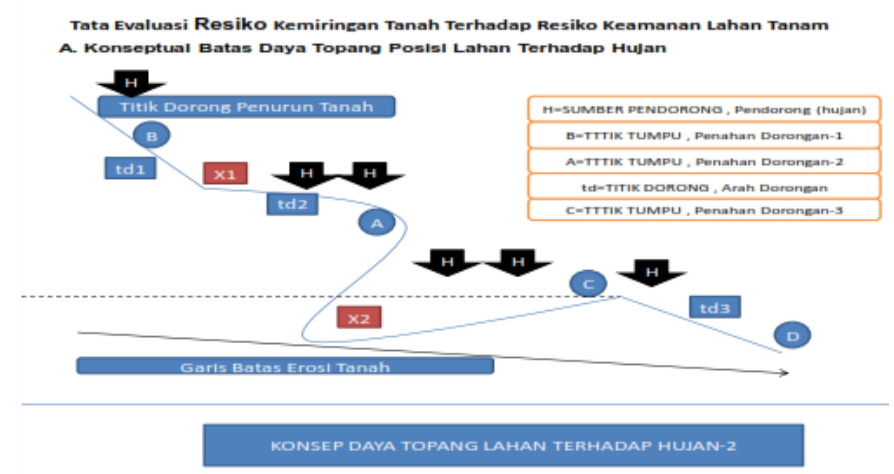

Gambar 8. Tata Evaluasi Resiko Kemiringan Tanah Terhadap Resiko Keamanan Lahan

Tanam

Berdasarkan gambar diatas, terjadi perubahan dinamika bentuk hamparan lahan akibat dari erosi tanah akibat beban yang diterima oleh bentangan lahan dalam jangka waktu tertentu. Pada kondisi ini diperlukan kebijaksanaan kajian lebih hati-hati agar dalam pengambilan keputusan pemilihan lahan tidak terjadi kerugian dalam hasil produksi komoditi yang dikembangkan pada lahan ini, akibatnya produksi mengalami perubahan akibat adanya fenomena alam yang berubah dan kemungkinan resiko lanjutan dari lingkungan. Pengkajian keaman lahan dititik beratkan pada analisis lapangan di awal 
Prosiding Seminar Nasional Pembangunan dan Pendidikan Vokasi Pertanian

Politeknik Pembangunan Pertanian Manokwari, 14 November 2020

e ISSN : 2774-1982

sebelum dilakukan prioritas penanaman dan jenis komoditi yang akan dikembangkan, keamanan lahan dari resiko perubahan lingkungan harus menjadi dasar utama kebijakan lahan dan juga untuk pemilihan awal lokasi atau lahan penanaman (Nora, 2020b).

Kondisi diatas merupakan kondisi yang memiliki kecirian khusus lahan dengan instrument yang lebih bervariasi dan lebih banyak hasil tetapan pengukuran yang didapatkan karena kondisi lahan tersebut berubah-ubah terkadang memerlukan waktu yang panjang atau bahkan berlangsung terus menerus baik dalam jangka waktu pendek, jangka waktu menengah atau jangka waktu panjang. Pada kondisi ini pengukuran dan analisis lahan perlu kajian yang terus menerus tergantung pada perubahan yang terjadi tersebut(Nora, 2020b).

Pada gambar diatas bahwa instrument utama yang harus diukur adalah posisi pada peta Citra Media Tulis (CMT) meliputi1) titik posisi utama puncak (P); titik-titik bagian dari alur puncak (a1.1,a1.2,a1.3 dan seterusnya) pada garis pembentuk sudut-sudut puncak yang sama pada arah garis yang sama dari puncak utama $(\mathrm{P}), 2)$ garis melintang penghubung antar sudut-sudut utama dari kedua sisi titik-titik alur puncak, 3) garis tegak lurus yang berada didalam area A sebagai penghubung antara sudut vertikal pada puncak A dan garis searah yang sama pada bagian A1 dan garis yang sama pada A2 yang merupakan dua bagian dari penyusun utama bentuk puncak A, 4) posisi garis utama gambar terdiri dari garis vertikal dan horizontal yang membagi dua gambar dengan ukuran yang sama serta garis diagonal pada kedua sisi gambar yang saling bersilangangan (Nora, 2020b).

Ditambahkan pula bahwaPengukuran dilanjutkan dengan menganalisis data yang ditemukan berdasarkan pengukuran instrument-instrumen terkecil pada data CMT berupa 1) pengukuran puncak beserta nilai rataan puncak yang didapat dari pembagian atara nilai puncak dengan jumlah garis utama yang terbentuk pada puncak A yaitu A, A1 dan A2 sehingga berjumlah 3 garis utama (P) dimana 3 adalah ketetapan, 2) analisis data sudut derajat masing-masing puncak (a1.1, a.12 dan seterusnya) pembentuk data utama A1 begitu juga untuk data A2,3) menentukan nilai total derajat keseluruhan, 4) menghitung nilai total penambahan titik-titik pembentuk puncak berdasarkan garis 1,2,3,4,5 dan seterusnya (bagian bawah dari gambr) atau dasar permukaan dataran tersebut dan membandingkannya dengan total jumlah data (P1), 5) hasil nilai P1 digunakan untuk menentukan P2 dengan cara mengurangi nilai $\mathrm{P} 1$ dengan jumlah data $\mathrm{P} 1,6)$ pengukuran $\mathrm{P} 3$ didapat dari nilai $\mathrm{P} 2$ dibandingkan dengan jumlah data (P1). 
Prosiding Seminar Nasional Pembangunan dan Pendidikan Vokasi Pertanian Politeknik Pembangunan Pertanian Manokwari, 14 November 2020

e ISSN : 2774-1982

Menurut Nora (2020a) berdasarkan informasi beberapa literasi tentang tata letak ruang lahan terdapat beberapa informasi yaitu 1) dataran sangat tinggi, 2) dataran tinggi, 3) dataran curam, 4) dataran landai dan 5) dataran datar. Dari instrument informasi diatas bahwa untuk menilai suatu dataran sangat penting terkait dengan jenis sumber daya yang adaptif dalam lingkungan tersebut secara alamiah, untuk memberikan informasi yang tepat tentang suatu komposisi botani diperlukan pengukuran khusus pada sampel lahan tersebut sebagai pendekatan kajian lahan PS (Planning System).

Karakteristik dapat dilihat dari visualisasi posisi lahan dengan pengukuran instrument tertentu yang ditetapkan sebelum dilakukan pengamatan lahan. Ketepatan instrument-instrumen tersebut memberikan bantuan informasi pendekatan nilai suatu posisi lahan yang tepat. Ada beberapa metode yang digunakan dalam hal ini dari sistem metode yang rumit dan panjang sampai pada metode yang hanya pengukuran langsung saja. Namun metode yang diperlukan sebagai kebaruan metode sangat diperlukan untuk dapat ditemukan dengan tujuan praktisi dan barometer tepat yang lebih sederhana sehingga bisa diterapkan secara langsung maupun tidak langsung yang hanya menggunakan data pokok lahan yang diperlukan sebagai basis data utama. Arah informasi sumber daya akan memberikan informasi arah kebijakan pemanfaatan lahan sebagai sumber daya yang dapat dikelola dengan metode menyeluruh dan bersifat integrasi informasi tentang sumber daya suatu wilayah (Nora, 2020a).

Untuk pemahaman hasil nilai yang didapat dari lapangan dengan menggunakan metode tahap kedua ini, dapat dilihat dari contoh instrument pada tabel berikut.

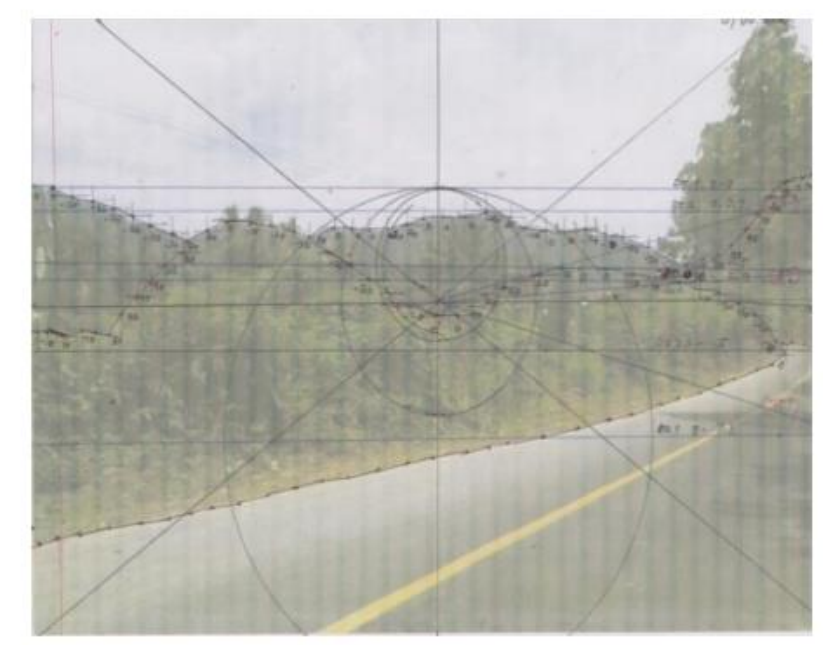

Gambar 9. CMF Lokasi M-8 Di Lapangan (A) 
Prosiding Seminar Nasional Pembangunan dan Pendidikan Vokasi Pertanian Politeknik Pembangunan Pertanian Manokwari, 14 November 2020

e ISSN : 2774-1982

\section{E. Teknis Pengukuran Tahap-2}

Berdasarkan hasil dari CMF menunjukkan bahwa data yang diinfentarisir meliputi data derajat- derajat line, RK Aman, jumlah titik-titik derajat yang membentuk garis vertical dan horizontal yang menghasilkan garis hubung berupa petakan-petakan utama dalam CMT (A). Adapun gambar dapat dilihat diatas.

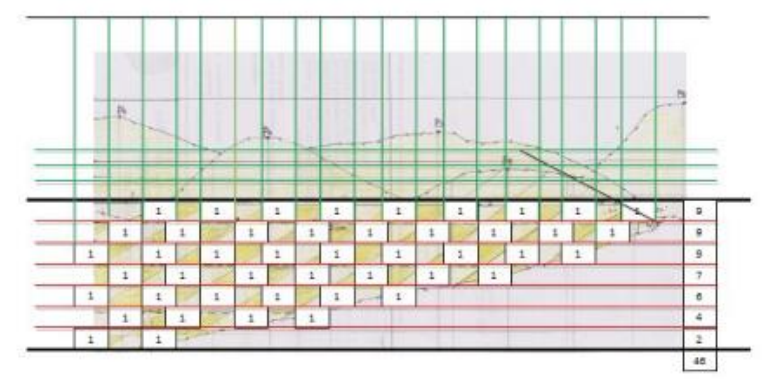

Gambar 10. Teknik Pengukuran Tahap-2

\section{F. Teknis Pengukuran Tahap-2}

Data-data yang diperoleh dari pada CMF Dokumentasi dilanjutkan dengan mengelompokkan data berdasarkan lokasi sampel pada suatu daerah dan banyaknya derajat yang terbentuk dan rataan interval derajat masing-masing lokasi yang digunakan untuk mengetahui petakan-petakan setiap lokasi yang berbeda-beda dan karakteristik data yang dapat diambil informasinya.

Tabel 64. RK Aman Lokasi M-8 (22-09-2020)

\begin{tabular}{|c|c|c|c|c|c|c|c|}
\hline Kode & & & Line & & & & \\
\hline & $\mathbf{A}$ & B & $\mathrm{C}$ & D & $\mathbf{E}$ & Jumlah & Rataan \\
\hline & Lokasi & Lokasi & Lokasi & Lokasi & Lokasi & Line & Line \\
\hline \multirow[t]{2}{*}{ M-1 } & 43 & 37 & 0 & 0 & 0 & 80 & 40 \\
\hline & 0 & 0 & 0 & 0 & 0 & & \\
\hline Jumlah & 43 & 37 & 0 & 0 & 0 & 0 & \\
\hline $\begin{array}{c}\text { Derajat } \\
\text { M-1 }\end{array}$ & $-30 \mathrm{~s} / \mathrm{d} 20$ & $0 \mathrm{~s} / \mathrm{d} 30$ & $0 \mathrm{~s} / \mathrm{d} 30$ & $0 \mathrm{~s} / \mathrm{d} 30$ & $0 \mathrm{~s} / \mathrm{d} 30$ & & \\
\hline
\end{tabular}

Sumber : Hasil Penelitian (Agustus, 2020)

CMT diatas menunjukkan bahwa posisi banyaknya petakan dapat dilihat berdasarkan trapesium-trapesium yang terbentuk. Adapun pengukuran lahan dapat dilihat pada gambar dibawah ini. 


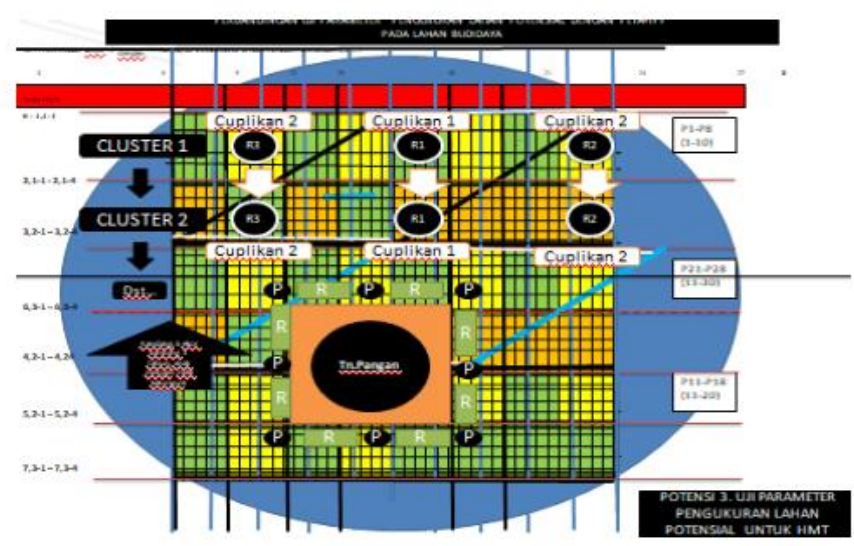

Gambar 10. Manajerial Data Cluster Pengukura Produksi HMT Lahan Secara Umum

Manajerial data cluster dalam pengukuran produksi HMT ditujukan untuk mengatur data perhitungan setiap bagian unit keseluruhan dari lahan setara 1 hektar atau lebih, untuk unit yang lebih dari 4 unit maka dihitung lebih dari 1 hektar sesuai jumlahnya dengan ketentuan 1 hektar terdiri dari 4 unit petakan.

\section{KESIMPULAN DAN SARAN}

Produktifitas lahan M-8 memiliki kekuatan potensi produksi dari perhitungan dengan CMT adalah sebesar 2.530 dengan berat $(\mathrm{kg})$ /populasi rata-rata. Lokasi Kabupaten Merangin tidak termasuk dalam lokasi terpilih dalam Basic Mapping namun memiliki potensi untuk pengembangan HMT dengan topografi yang berbukit (konsep dasar survey awal lapangan) : 1) persiapan foto lahan secara vertikal (tinggi-rendah) lokasi dapat dilihat dari dokumentasi lahan pada analisis grafis dengan metode pengukuran matematis yang meliputi : a) penandaan titik-titik pada batas gambar pada dokumentasi untuk mendapatkan citra media tulis pada lembaran yang akan diukur dengan memberikan tanda batas dataran tinggi, sedang dan rendah yang mudah dilihat pembedanya dan memberikan garis-garis pembantu seperti garis vertikal dan horizontal beserta sudut pandang dalam derajat ketinggian secara vertical, b) pengukuran produksi dapat dilakukan sesuai dengan kondisi lahan apakah lahan tersebut merupakan lahan budidaya (optimal) maupun lahan non budidaya (sub optimal). Manajerial pengukuran produktifitas lahan dengan menghitung :

A.Pengelolaan Data Pengukuran Produksi Lahan Budidaya (Nora, 2020)

Pengukuran Produksi Hijauan Menurut Peta TPP dilakukan dengan tahapan : 1) dimulai dari titik yang telah ditentukan kemudian cuplikan-cuplikan diambil dan jarakjarak tertentu sepanjang garis yang memotong padang rumput dengan langkah-langkah sebagai berikut,2 ) dan teknis Peta TPP dilakukan dengan metode hasil komputerisasi yang 
Prosiding Seminar Nasional Pembangunan dan Pendidikan Vokasi Pertanian

Politeknik Pembangunan Pertanian Manokwari, 14 November 2020

e ISSN : 2774-1982

akan memberikan informasi tentang jumlah petakan yang dihasilkan (jumlah petakan dijadikan dasar penentuan petakan yang akan dibuat.

B. Pengelolaan Data Produksi Lahan Sub Optimal (Nora, 2020c)

Pengaturan pengelolaan data produksi seperti tahapan dibawah ini : 1) hasil pengelolaan pengukuran lahan berdasarkan kuadran dengan metoda TPP diterapkan sesuai dengan tahapan yang ditentukan untuk menghitung produksi hijauan, 2) pengambilan cuplikan sampel yang akan diukur berdasarkan ketentuan bahwa setiap luasan 1 hektar lahan terdiri dari 4 bagian besar lahan dengan kode lahan A,B, C dan D, 3) jumlah Trapesium akan ditampilkan berdasarkan pada pengaturan plot yang muncul, 4) pola tanam pada lahan budidaya juga dapat dihitung dengan menggunakan Peta TPP sejak awal pengambilan sampel produksi HMT sebagai gambaran potensi suatu lokasi.

C. Pengelolaan Data Produksi Lahan Sub Optimal

Sedangkan untuk Pengaturan pengelolaan data produksi seperti tahapan : 1) hasil pengelolaan pengukuran lahan berdasarkan kuadran dengan metoda TPP diterapkan sesuai dengan tahapan yang ditentukan untuk menghitung produksi hijauan (Sama dengan lahan optimal) dengan perbedaan yaitu : 1) pengukuran khusus lahan budidaya, 3) luasan lahan 12 petakan pengaturan tanam dalam 1 hektar lahan, 4) pola masa panen yang ditentukan, biasanya antara 40-60 hari, 5) Masa tanam diperoleh dari kombinasi jumlah Trapesium akan ditampilkan berdasarkan pada pengaturan plot yang muncul 1) Teknis Pengukuran Tahap-1Teknik pengukuran produksi diawali CMF berdasarkan hasil dokumentasi yang dilanjutkan dengan CMT. Instrument-instrumen pengukuran sebagai berikut : 1) Menggunakan media tertulis mengikuti derajat-derajat pada CMF untuk mengetahui RK Aman, penampang utama grafis lahan, tata kelola lahan dengan strategi resiko kemiringan lahan, 2) Teknis Pengukuran Tahap-2.

\section{DAFTAR PUSTAKA}

Agusyanto, P. (1991). Alternatif Ketersediaan Hijauan Makanan Ternak Sepanjang Tahun di Lahan Kering. Departemen Pertanian Balai Informasi Pertanian Bali. Proyek Pengembangan Penyuluhan Pertanian Pusat/National Agricultural Extension Project.

Agus, S. (1995). Pedoman Teknis Perluasan Areal Kebun Hijauan Makanan Ternak. Kementrian Pertanian, Jakarta.

Azmi \& Gunawan. (2007). Usaha Tanaman Ternak Kambing Melalui Sistem Integrasi. Balai Pengkajian Teknologi Pertanian Bengkulu, Bengkulu. Seminar Nasional Teknologi Peternakan dan Veteriner. Hal : 523-531. 
Prosiding Seminar Nasional Pembangunan dan Pendidikan Vokasi Pertanian

Politeknik Pembangunan Pertanian Manokwari, 14 November 2020

e ISSN : 2774-1982

Abdullah. (2008). Pembuatan Jerami Padi Amoniasi Sebagai Sumber pakan Ternak Potensial di Kecamatan Ujuang Loe Kabupaten Bulukumba, Program Penerapan IPTEKS.

Ako, A., Fatma, Jamila, \& S. Baba. (2012). Produksi dan Kualitas Susu Sapi Perah Yang Diberi Silase Complete Feed Berbahan Baku Limbah Pertanian. Laporan Hasil Penelitian, Fakultas Peternakan Universitas Hasanuddin.

BEETS, W.C. (1982). Multiple Cropping and Tropical Farming Company Limited England.

Boyon, Arfa'i. (1996). Potensi Ekonomi Ternak Sapi Potong dalam Sistem Usahatani pada Berbagai Topografi Lahan di Kabupaten Agam, Sumatera Barat (Laporan Penelitian). Padang: Lembaga Penelitian Universitas Andalas.

Chaniago, T. (2009). Perspektif Pengembangan Ternak Sapi di Kawasan Perkebunan. Prosiding Workshop Nasional Dinamika dan Keragaan Sistem Integrasi TernakTanaman: Padi, Sawit, Kakao (In Press). Pusaat Penelitian dan Pengembangan Peternakan. Bogor.

Dominy, F.S. (2000). Organic Fish: A Niche too Far. Dalam Feed International, Vol.21 No. 11 November 2000.

Diwyanto K. (2002). Pemanfaatan sumber daya local dan inovasi teknologi dalam mendukung pengembangan sapi potong diindonesia ( orasi APU ). Bogor : Badan Litbang Pertanian.

Direktorat Jendral Peternakan. 2013. Statistik Peternakane dan Kesehatan Hewan. Livestock and Animal Health Statistics. Penerbit PT. CV. Alnidra Dunia Perkasa. Kementrian Pertanian.

Elly, F.H, et al. (2013). Introduksi Hijauan makanan Ternak Sapi di minahasa Selatan.Pastura. Volume 3 No. 1. Tahun 2013. ISSN 2088-818X.

Farizaldi. (2011). Produktifitas Hijauan Makanan Ternak Pada Lahan Perkebunan Kelapa Sawit Berbagai Kelompok Umur di PTPN 6 Kabupaten Batang Hari Propinsi Jambi. Jurnal Ilmiah Ilmu-Ilmu Peternakan November 2011, Vol. XIV No. 2. Fakultas Peternakan Universitas Jambi.

Gardner, F.P., R. B. Pearce \& R. I. Mitchel. (1985). Phisiology of Crop Plants. Low. AS.

Hernanto, F. (1996). Ilmu Usaha Tani. Cetakan ke 7. Penebar Swadaya, Jakarta

Manti, I. Azmi, E. Priyotomo \& D. Sitompul. (2003). Kajian Sosial Ekonomi Sistem Integrasi Sapi dengan Kelapa Sawit (SISKA). Prosiding Lokakarya Nasional Sistem Integrasi Kelapa-Sapi. Bengkulu, September 2003. Pusat Peneltian dan Pengembangan Peternakan, Bogor.

Hermawan A \& B. Utomo. (2013). Peran Ternak Ruminansi Dalam Pengembagan Sistem Usaha Tani Konservasi Di lahan Kering DAS Bagian Hulu. Prosiding. Seminar Nasional Peternakan Berkelanjutan. Inovasi Agribisnis Peternakan Untuk Ketahanan Panggan. Fakultas Peternakan Universitas Padjadjaran, Bandung. P:112-117.

Hasyim A. (2016). Ekonomi Makro. Penerbit Prenadamedia Group, Jakarta.

Nora, D. (2015). Konservasi Potensi Daerah Untuk Pengembangan Lanjutan Pada Lokasi Inflasi dan Stok Minim Sapi Potong Kabupaten Bungo. Penelitian Dosen Pemula. 
Prosiding Seminar Nasional Pembangunan dan Pendidikan Vokasi Pertanian

Politeknik Pembangunan Pertanian Manokwari, 14 November 2020

e ISSN : 2774-1982

Nora, D. (2016). Peta Lokasi Konservasi Untuk Penyelamatn Stok Ternak. Hasil Penelitian Individu dan Seminar Nasional dengan Tema "Pembangunan Inklusif Desa-Kota" Kerjasama PPS PWD-UA dan ASPI-PERHEPI di Universitas Andalas, Padang

Nora, D. (2017). Potensi dan Strategi Pengembangan Usaha Sapi Potong Di Kabupaten Bungo. Tesis. PPS- Ilmu Peternakan Universitas Andalas, Padang.

Nora, D. (2018). Basic Mapping Data Of Jambi Province Potency For A Continous Lifestock Development Strtegy. International Converence. Proceeding ICAPS dan PPS Universitas Andalas, Sumatera Barat.

Nora, D. (2020a). Konseptual Mapping Sumber Daya Di Propinsi Jambi. Jurnal Stock Peternakan. Vol. 2 No.1 Tahun 2020. Program Studi Peternakan Fakultas Pertanian Universitas Muara Bungo.

Nora, D. (2020b). Konseptual Mapping Pemasaran Sumber Daya Di Propinsi Jambi. Jurnal Stock Peternakan. Vol. 3 No.1 Tahun 2020. Program Studi Peternakan Fakultas Pertanian Universitas Muara Bungo.

Nora, D. (2020c). Conceptual Mapping of Land Resources Management With TPP Map (Technical Study of The TPP Map Usage System). Agricultural Science Research Journal. International Research Journal. RES Journal.

Gardner, F.P., B. Pearce \& R. I. Mitchel. (1985). Phisiology of Crop Plants. Low.AS.

Gusmeroli, F., G.D. Marianna, F. Fava, A. Monteiro, S. Bocchi, \& G. Parolo. 2013. Effect of Ecological, Landscape and Management Factors On Plant Species Composition, Biodiversity and Forage Value Ain Alpine Meadows, Grass and Forage Science. Vol. 68, Issue 3: 437-447.

Husch, B. (1987). Perencanaan Inventarisasi Hutan. Penerbit Universitas Indonesia, Jakarta.

Ismu. I. (2010). Penerapan Sistem Tiga Strata (STS) Sebagai Barrie Removal Di Taman Nasional Bali Barat (TNBB). TNBB Bali.

Junaidi. (2008). Ekonomi Sumber Daya Alam. Bung Hatta University Press.

Jaya, M et al. (2015). Gagalnya CSR Agribisnis. GRE Publishing, Yogyakarta.

Kartasapoetra. G. Et all. (1986). Marketing Produk Pertanian dan Industri. PT. Bina Aksara,Jakarta.

Karungu, F. (1992). Analisis Liniar Programing Ternak Sapi Sebagai Ternak Kerja Dalam Usaha Tani Kelapa Di Kecamatan Likupang. Laporan Penelitian. Fakultas Peternakan Universitas Sam Ratulangi (Unsrat), Manado.

Kartono, G. (2002). Pengelolaan Sumber Daya Lahan Dalam Upaya Peningkatan Pendapatan Petani dan Keberlanjutan Sistem Usaha tani. Prosiding. Seminar Nasional Inovasi Teknologi Tepat Guna Berorientasi Agribisnis Untuk Pemberdayaan Pertanian Wilayah. Puslitbang Sosek Pertanian Bogor.

Kleden, M.M. (2001). Produksi Rumput Alam Dalam Mendukung Pengembangan Sapi Potong di Kecamatan Lebatukam Kabupaten Lembata. Jurnal Informasi Pertanian Lahan Kerin. Pusat Penelitian Lahan Kering Lembaga Penelitian Universitas Nusa Cendana Kupang. No. 8 Januari 2001.

Kariyasa K., E. \& Pasandaram, 2004. Dinamika Struktur Usaha dan Pendapatan Tanaman Ternak Terpadu. Makalah disampaikan dalam Seminar Kelembagaan Usahatani 
Prosiding Seminar Nasional Pembangunan dan Pendidikan Vokasi Pertanian

Politeknik Pembangunan Pertanian Manokwari, 14 November 2020

e ISSN : 2774-1982

Tanaman Ternak tanggal 30 Nopember - 2 Desember 2-4 Di Denpasar-Bali, Proyek PAATP. Jakarta.

Kariyasa K. \& E. Pasamdaram. 2004. Dinamika Struktur Usaha dan Pendapatan Tanaman Ternak Terpadu. Makalah disampaikan dalam Seminar againbagaan Usahatani Tanaman Ternak tanggal 30 Nopember-2 Desember 2004 di Denpasar-Bali. Proyek PAATP. Jakarta.

Kementerian Petanian, 2010. Peningkatan Nilai Tambah dan Daya Saing Produk Pertanian Dengan Pemberian Insentif Bagi Tumbuhnya Industri Pedesaan. Blue Print. Kementerian Pertanian, Jakarta.

Lukman, H. \& Mursidi. (1987). Pengelolaan Bahan Organik Tanah Dengan Kombinasi Pertanian Tanaman Pangan dan Pupuk Hijau. Prosiding. Pertemuan Tenis 1985. PPT. Bogor.

Magribi, M. (1999). Geografi Transportasi. PPS UGM, Yogyakarta.

Muhakka, Napoleon, A., \& Rosa, P. 2012. Pengaruh Pemberian Pupuk Cair Terhadap Produksi Rumput Gajah Taiwan (Pennisetum purpereum Schumach).PT Bumi Aksara : Jakarta.

Mandarisa. (2013). Perspektif Pembangunan Peternakan Rakyat. Andalas University Press. Sumatera Barat.

Nitis, I.M., K. Suarna, W. Sukanten, S. Putra, \& W. Datera. 1986. Three Strata System for Cattle Feeds and Feeding in Dry Land Farming Area in Bali. Faculty of Animal Husbandry. Nutrition and Tropical Forage Science. Udayana University Denpasar.

Nitis, I.M., K. Suarna, W. Sukanten, S. Putra, \& W. Arga. (1989). Three Strata System For Cattle Feds dan Feeding in Dry and Farming Ara in Bali. Final Report to IDRC.Canada.

Nitis, I.M., K. Suarna, W. Sukanten, S. Putra, \& W. Arga. (1994). Growth an Reproductive Performance of Bali Heifer under Three Strata Forage System. Report to FAO. Project No AGAP-653AN 40/5. Home.

Nitis, I.M., K. Suarna, \& A.W. Puger. (2000). Pengalaman Pengembangan Tanaman Ternak Berwawasan Lingkungan di Bali. Jurusan Nutrisi dan Makanan Ternak, Fakultas Peternakan. Universitas Udayana, Denpasar. Bali. Seminar Nasional Sistem Integrasi Tanaman-Ternak. Hal : 44-52.

Nitis, I.M., K. Suarna, \& K. Lana. (2001). Peningkatan produktivitas dan Kelestarian Lingkungan Pertnian Lahan Kering Dengan Sistem Tiga Strata (STS). Makalah disajikan dalam Seminar Regional Sehari "Optimalisasi Lahan Kering Untuk Usaha Pertanian DalamArti Luas" Fakultas Pertanian Unwar, Denpasar.

Nitis, I. M., K. Lana., \& A.W. Puger. (2009). Pengalaman Pengembangan Tanaman Ternak Berwawasan Lingkungan di Bali. Jurusan Nutrisi dan Makanan Ternak. Fakultas Peternakan Universitas Udayana, Denpasar Bali. Seminar Nasional Sistem IntegrasiTanaman Ternak. (Hal : 44-52)

Novyta .C, dkk. Potensi Hijauan Pakan dan Kapasitas Tampung Ternak Sapi Di Bawah Pohon Kelapa Di Kecamatan Tabukan Utara Kabupaten Kepulauan Sangihe. Jurnal LPPMBidang Sains dan Teknologi. Volume 4 Nomor 2 November 2017, Manado.

Prawidiputra, B.R. (1979). Komposisi Botanis Padang Rumput Alam di Sulawesi Selatan. Bulletin LPP No. 22, Bogor. 
Prosiding Seminar Nasional Pembangunan dan Pendidikan Vokasi Pertanian

Politeknik Pembangunan Pertanian Manokwari, 14 November 2020

e ISSN : 2774-1982

Purwanto, I. (2003). Manajemen Strategi. Penerbit Yrama Widya, Bandung.

Partama, I.G.B., D.P.M.A Candrawati, I.W. Sudiastra, N.N. C. Kusumawati, I.G, \& N. Kayana. (2013). Penerapan Sistem Tiga Strata (STS) Untuk Mengatasi Msalah Hijauan makanan Ternak Pada Petani Ternak Sapi di Desa Pengotan Kabupaten Bangli. Jurnal Udayana Mengabdi 12 (2) : 6063.

Pemayun, T.G.O, S. Putra \& W. Puger. (2014). Penampilan Reproduksi Sapi Bali Pada Sistem Tiga Strata. Jurnal Kedokteran Hewan Vol. 8 (1) : 60-63.

Reksohadiprodjo, S. (1987). Manajemen Pengolahan Pada Perusahaan Perkebunan. BPFE Yogryakarta.

Rusli, S. (2012). Pengantar Ilmu Kependudukan. LP3ES, Jakarta.

Santoso, P. (1980). Analisa Usahatani di Kaupaten Kediri. Bulletin ortikultura VIII (7).

Susetyo. (1980). Padang Penggembalaan. Departemen Ilmu Makan Ternak. Fakultas Peternakan I.P.B Bogor.

Soekartawi. (1990). Teori Ekonomi Produksi. Dengan Pokok Bahasan Analisa Fungsi Cobb-Douglas. Jakarta: Rajawali Press. IIp.

Soedarmadi, H., L. Abdullah, \& S. Jayadi. (1996). Daya Dukung Hijauan Pakan Terhadap Peningkatan Populasi Ternak Rumnansia di Indonesia. Seminar Nasional Hijauan Pakan. Lembaga Penelitian Universitas Padjadjaran Bandung

Sajimin, dkk. (1999). Integrasi Tanaman Pakan Pada Sistem Usaha Tani Di Kecamatan Bayongbong Kabupaten Garut. JITV Vol. 4 No. 4 tahun 2009.

Sutarno. (2004). Ketersediaan Hijauan Pakan Berkesinambungan Melalui Sitem Tiga Strata Dalam Rangka Meningkatkan Produktivitas Petani Ternak Kambing. Lembaga Swadaya Masyarakat Kelompok Studi Pembangunan Untuk Masyarakat Unggaran.

Sugeng, Y.B. (2006). Sapi Potong. Enebar Swadaya, Jakarta. Yogyakarta.

Sunyoto, D. (2009). Analisis Regresi dan Uji Hipotesis. Media Pressindo

Sudarwati, H., O. Sofjan, \& H.E. Sulistyo. (2010). Penanaman Legum Pohon "Sistem Tiga Strata" Sebagai Sumber Protein Pakan Berbasis Tanin di Sentra Ternak Kambing Wilayah Konservasi Hui An Kecamatan Ampel gading Kabupaten Malang. Jurnal Mitra Akademika Vol. 15 September 2010.

Suresti, A. \& Wati, R. (2012). Strategi Pengembangan Usaha Peternakan Sapi Potong di Kabupaten Pesisir Selatan. Jurnal Peternakan Indonesia, vol. 14 (1) : 249-262.

Salendu, A.H.S. (2012). Perspektif Pengelolaan Agroekosistem Kelapa-Ternak Sapi di Minahasa Selatan. Disertasi Doktor. Program Pascasarjana Fakultas Pertanian Universitas Brawijaya, Malang.

Sukandarrumidi. (2014). Pemetaan Geologi. Gadjah Mada University Press. Anggota Ikapi. Yogyakarta.

Supriadi. (2015). Implementasi Inovasi Teknologi Sistem Penyediaan Hijauan Makanan Ternak Di Lahan Kering di Yogyakarta.Planta Tropika Journal Of Agro Science Vol. 3 No. 2/Agustus2015. 
Tohari. Pudji Lestari \& Djoko Muljanto. (1996). Kajian Adaptasi Kultivar Gude (Cajanus cojan (L) Millsp.) Terhadap Kekeringan. Berkala Penelitian Pasca Sarjana. Universitas Gadjah Mada. Yogyakarta. Jilid 9 Nomor 1B Februari 1996.

Tarigan, R. (2010). Perencanaan Pembanguna Wilayah. Penerbit Bumi Aksara, Jakarta.

Wilar, A. F, H.J. Somie, F.M. Karungu \& S.K Dotulong. (1991). Penelitian Pemanfaatan Areal Dibawah Pohon Kelapa Melalui Introduksi Ternak Ruminansia Di Sulawesi Utara. Laporan Penelitian Fakultas Peternakan Unsrat, Manado.

Yusriani. Y. dkk. (2015). Kajian Pemanfaatan Limbah Jerami Sebagai Pakan Ternak Sapi di Propinsi Aceh. Jurnal Peternakan Indonesia. Vol 17 (2). ISSN 1907-1760. 